\title{
Energetics, thermoregulation and torpor in the Chilean mouse-opossum Thylamys elegans (Didelphidae)
}

\author{
Energética, termorregulación y sopor en la yaca Thylamys elegans (Didelphidae)
}

FRANCISCO BOZINOVIC ${ }^{1}$, GRICELDA RUIZ $^{2}$, ARTURO CORTÉS $^{3} \&$ MARIO ROSENMANN 4

\author{
${ }^{1}$ Center for Advanced Studies in Ecology \& Biodiversity and Departamento de Ecología, Facultad de Ciencias Biológicas, \\ Pontificia Universidad Católica de Chile, Santiago 6513677, Chile \\ ${ }^{2}$ Departamento de Biología, Universidad Metropolitana de Ciencias de la Educación, Casilla 147, Santiago, Chile \\ ${ }^{3}$ Centro de Estudios Avanzados de Zonas Áridas, and Departamento de Biología. Facultad de Ciencias, \\ Universidad de La Serena, Casilla 599, La Serena, Chile \\ ${ }^{4}$ Departamento de Ciencias Ecológicas, Facultad de Ciencias, Universidad de Chile, Casilla 653, Santiago, Chile; \\ E-mail of corresponding author: fbozinov@bio.puc.cl
}

\begin{abstract}
In this paper we studied the energetics and thermoregulation of the Chilean mouse-opossum Thylamys elegans (Dielphidae) a nocturnal small marsupial, endemic of southern South America. We studied their standard energetic and determined whether they exhibit shallow daily torpor or deep prolonged torpor as a function of ambient temperature and food availability. Thylamys elegans partially supports the hypothesis that Neotropical marsupials have somewhat a higher basal metabolic rate (BMR) and thermal conductance $\left(\mathrm{C}_{\mathrm{m}}\right)$ than Australian ones. In fact, BMR was higher but $\mathrm{C}_{\mathrm{m}}$ was lower than expected for their body mass. The higher mass-independent BMR of the Chilean mouse-opossum may be explained by its insectivorous food habits and its low $\mathrm{C}_{\mathrm{m}}$ by its temperate habitats. Euthermic Chilean mouse-opossum showed daily fluctuations in body temperature being significantly higher during night time. In addition T. elegans entered in daily torpor and aroused spontaneously only was food was absent. That is, this species display a facultative type of daily torpor because propensity to enter in torpor was dependent of the combination of food absence and low ambient temperature. No torpor was observed when food was available. During torpor ambient temperature was slightly above ambient temperature between 0.3 to $0.5^{\circ} \mathrm{C}$. Torpor in this species as well as in marsupials in general, appears to be a flexible and an opportunistic response to unpredictable environmental conditions.
\end{abstract}

Key words: South America, Chile, marsupials, energetic, thermoregulation, facultative torpor.

\section{RESUMEN}

Estudiamos la energética y termorregulación de Thylamys elegans o "yaca" (Dielphidae) un marsupial pequeño y endémico de Sudamérica. Estudiamos su energética estándar y determinamos si presentan estados de sopor superficial o profundo en función de la temperatura ambiente y la disponibilidad de alimento. Thylamys elegans apoya de manera parcial la hipótesis que sostiene que los marsupiales neotropicales poseen tasas metabólicas basales (BMR) y conductancias térmicas $\left(\mathrm{C}_{\mathrm{m}}\right)$ más altas que los australianos. En efecto BMR fue alta pero $C_{m}$ fue menor que la esperada para la masa corporal. La BMR masa-independiente elevada de la yaca podría ser explicada por sus hábitos tróficos insectívoros y su $\mathrm{C}_{\mathrm{m}}$ baja por vivir en hábitat templados. Durante eutermia la yaca muestra fluctuaciones en la temperatura corporal siendo significativamente mayores durante la noche. Además, $T$. elegans entra y sale del sopor diario en forma espontánea solamente en ausencia de alimento. Es decir, esta especie muestra sopor del tipo facultativo pues este dependió de la interacción entre la ausencia de alimento y la temperatura ambiental. No se observaron estados de sopor cuando existió alimento disponible Durante el sopor la temperatura del cuerpo entre 0,3 a 0,5 ${ }^{\circ} \mathrm{C}$ superior a la del ambiente. El sopor en esta especie así como en marsupiales en general parece ser una respuesta flexible y oportunista a la variabilidad del ambiente.

Palabras clave: Sudamérica, Chile, marsupiales, energética, termorregulación, sopor facultativo.

\section{INTRODUCTION}

Torpor in small endotherms is a well-studied example of energy budget regulation. Theoretically, torpor is often hypothesized to be responsible for allowing some organisms to adjust to changing biotic and abiotic environmental conditions, through increases in survival under harsh environmental conditions (Humphries et al. 2003). Thus, torpor is an 
energy and water-conserving mechanism used by many species of small endotherms (SchmidtNielsen 1987, Geiser 1994, Holloway \& Geiser 1995, Cryan \& Wolf 2003). Torpor is characterized by a decrease in body temperature and a decline in metabolism of c.a. $90 \%$, in comparison to euthermy (Geiser 1994, Ortmann \& Heldmaier 1997). This relationship between torpor, ambient temperature and food availability has been well documented for many years. For example, Hainsworth et al. (1977) suggested that daily torpor is used by hummingbirds exclusively when food is scarce. Extensive use of torpor by a population should also be advantageous when food is scarce. Indeed, food supply appears to be an important factor influencing the annual period of inactivity of the rodent Perognathus longimembris, which may indicate torpor (Kenagy 1973). The mean duration of individual episodes of torpor increases for kangaroo mice when food supply is reduced (Brown \& Bartholomew 1969). On the other hand, ambient temperature largely explains the reduction of metabolism of daily heterotherms and hibernators (Geiser 1986, 1988, 1994, López-Calleja et al. 1997).

Small eutherian mammals and birds are classical examples of the processes listed above (for a review see McNab 2002). However, it is not well known what happens in other endotherms such as in South American marsupials (but see Bozinovic \& Rosenmann 1988a, 1988b, Caviedes-Vidal et al. 1990, Bozinovic \& Marquet 1991, for examples in some South American rodents). The physiology of torpor in marsupials is similar to eutherians in several aspects (Hallam \& Dawson 1993, Chappell \& Dawson 1994, Gibson \& Hume 2000, Holloway \& Geiser 2001). Nevertheless, with respect to energetics and thermal acclimation, some differences arise. Nespolo et al (2002) demonstrated that the potential for acclimatory response of thermogenic capacity in marsupials is controversial, reporting a significant effect of thermal acclimation on energy metabolism, organ masses and digestive enzyme activity in a Chilean mouse-opposum marsupial Thylamys elegans (Didelphidae). In the same species Silva-Durán \& Bozinovic (1999) tested the effect of food availability on energy expenditure and torpor (see also Roig 1971). They found that animals maintained with low food availability showed a higher frequency of torpor bouts in comparison to animals with high food availability, which never entered into torpor, hypothesizing that the reduction of energy expenditure achieved with torpor states by $T$. elegans is regulated through food availability.

In this study we followed the later approach to assess the effects of temperature and food availability on metabolic rate, thermoregulation and torpor bouts in this species which inhabits Mediterranean environments of central Chile.

Thylamys elegans shows conspicuous phenotypic flexibility in activity of intestinal enzymes, both, on a seasonal basis (Sabat \& Bozinovic 1994) and in response to diet acclimation (Sabat et al. 1995, Bozinovic \& Méndez 1997). In addition to the conceptual relevance of determining the underlying causes of observed differences in performance in a wild endothermic species, the scarcity of knowledge regarding the comparative physiology of South American marsupials will make this effort a valuable one. Consequently, the aim of this work is to determine in $T$. elegans the effect of changes in ambient temperature and food availability on metabolic rate, torpor state as well as on its frequency and regulation.

\section{MATERIAL AND METHODS}

Between 1982-1990 we studied a total of fifteen individuals (six males and nine females) with a mean body mass $\left(\mathrm{m}_{\mathrm{b}}\right)$ of $40.2 \pm 9.8 \mathrm{~g}$ (SD). Animals were captured in semiarid and Mediterranean scrublands of central Chile. This species feeds primarily on insects (Sabat \& Bozinovic 1994), and is strictly nocturnal. Animals were captured with Sherman traps, transported to Santiago, and individually maintained in large plastic cages with a photoperiod of $\mathrm{LD}=12: 12$ and ambient temperature of $20-25{ }^{\circ} \mathrm{C}$. Grapes, apples, eggs, grounded beef meat, worms and water were provided ad libitum.

Metabolic rate was measured during at least $1.5 \mathrm{~h}$ at different $\mathrm{T}_{\mathrm{a}}$ in a computerized closed respirometric system (Morrison 1951). $\mathrm{CO}_{2}$ and water vapor were absorbed inside the metabolic chamber through granules of Baralyme ${ }^{\mathrm{TM}}$ and Drierite $^{\mathrm{TM}}$ respectively. Body mass and $\mathrm{T}_{\mathrm{b}}$ were measured before and after the metabolic runs through $\mathrm{Cu}$-Constant thermocuples and BAT- 
12 digital thermometer. Minimal thermal conductance was calculated from the slope of the regression of $\mathrm{VO}_{2}$ versus $\mathrm{Ta}$ curve below the thermoneutral zone. Extrapolated $\mathrm{T}_{\mathrm{b}}$ fell within 1 SD of the average diurnal and nocturnal euthermic measured values of $T_{b}$, thus the theoretical classical assumption that $\mathrm{T}_{a}$ $=\mathrm{T}_{\mathrm{b}}$ when $\mathrm{VO}_{2}=0$ was satisfied. To determine BMR, animals were fasted for $3 \mathrm{~h}$ before beginning the measurements that were conducted in $850-\mathrm{mL}$ steel chambers at 30 and $32.5{ }^{\circ} \mathrm{C}$.

All $\mathrm{VO}_{2}$ values were corrected for STP (standard temperature and pressure). Body temperature was measured during day and night in euthermic animals as well as in torpid individuals through $\mathrm{Cu}$-Constantan thermocouples connected to a Baily digital thermometer. To test for a shallow or for a deep torpor response, continuous $\mathrm{VO}_{2}$ records were conducted in different individuals with food as well as, deprived of food (the most usual way to induce torpor, Lyman et al. 1982). Animals were exposed to a $L D=12: 12$, but at different $\mathrm{T}_{\mathrm{a}}$ ranging from 5 to $25{ }^{\circ} \mathrm{C}$. These measurements lasted for a minimum of $24 \mathrm{~h}$. In addition, to determine torpor regulation by effect of temperature, we changed it during $\mathrm{VO}_{2}$ measurements.

Comparisons between means were made through a one-way ANOVA and a post-hoc Tukey test, also a linear regression analysis was conducted to determine the thermal dependence of $\mathrm{VO}_{2}$. Results are reported as mean \pm 1 SD . Statistical analyses were performed using STATISTICA (6.0).

\section{RESULTS}

The effect of $\mathrm{T}_{\mathrm{a}}$ on $\mathrm{VO}_{2}$ of $T$. elegans is shown in Fig. 1. The resting $\mathrm{VO}_{2}$ below thermoneutrality increased in a linear form as $\mathrm{T}_{\mathrm{a}}$ decreased being represented by the following linear regression, $\mathrm{VO}_{2}=4.94-0.138( \pm 0.004)$ $\mathrm{T}_{\mathrm{a}}, \mathrm{r}=0.99, \mathrm{P}<0.0001$. The line intersects the abscissa at $35.8{ }^{\circ} \mathrm{C}$ a value within the range of diurnal and nocturnal recorded $\mathrm{T}_{\mathrm{b}}$ (see below). The slope of the curve $\left(0.138 \mathrm{mLO}_{2} \mathrm{~g}^{-1} \mathrm{~h}^{-1}{ }^{\circ} \mathrm{C}^{-1}\right)$ represents the minimal thermal conductance $\left(\mathrm{C}_{\mathrm{m}}\right)$ which was: $87.55 \%$ of the expected value for a similar size $(40.2 \mathrm{~g})$ standard mammal (i.e., $\mathrm{C}_{\mathrm{m}}=1.0 \mathrm{~m}_{\mathrm{b}}^{-0.5}$, Herreid \& Kessel 1967).

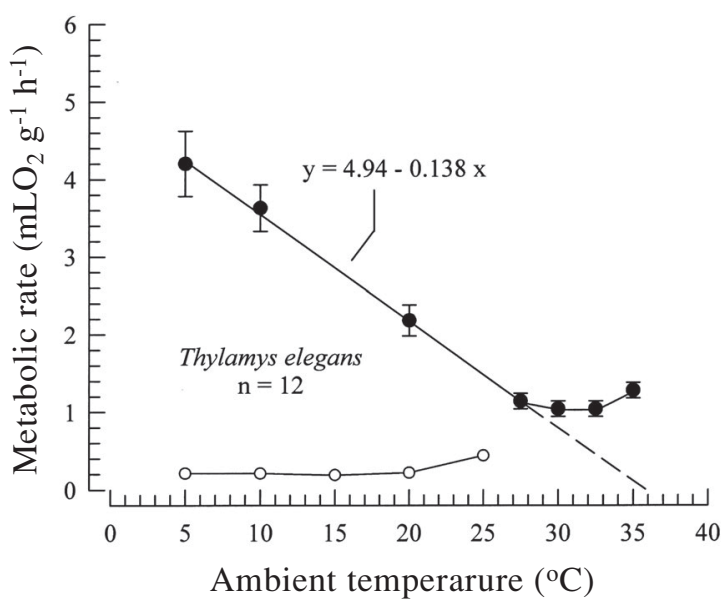

Fig. 1: Relationship between metabolic rate and ambient temperature in Thylamys elegans in euthermia (closed circles) and in torpor (hollow circles). Values are a mean of 12 animals $( \pm 1$ SD). See text for details.

Relación entre la tasa metabólica y la temperatura ambiente en Thylamys elegans durante eutermia (círculos cerrados) y sopor (círculos abiertos). Cada punto representa una media de doce animales $( \pm 1 \mathrm{DE})$. Véase el texto para detalles.

The basal metabolic rate was $1.07 \pm 0.01$ $\mathrm{mLO}_{2} \mathrm{~g}^{-1} \mathrm{~h}^{-1}{ }^{\circ} \mathrm{C}^{-1}(\mathrm{n}=12)$ which was a 112.3 .9 $\%$ of the predicted value for a standard metatheria $\left(\mathrm{BMR}=2.49 \mathrm{~m}_{\mathrm{b}}^{-0.26}\right.$ ) and $85.3 \%$ of the predicted value for a standard eutheria (BMR $\left.=3.53 \mathrm{~m}_{\mathrm{b}}{ }^{-0.28}\right)$ see $(\mathrm{McNab} 2002)$. The lower critical temperature of thermoneutrality was 27.5 ${ }^{\circ} \mathrm{C}$. A slight increase in $\mathrm{VO}_{2}$ was recorded at 35 ${ }^{\circ} \mathrm{C}$ (Fig. 1). In addition T. elegans exhibit torpor between 5 to $25{ }^{\circ} \mathrm{C}$ and only when food was absent (Fig. 1). During torpor $\mathrm{T}_{\mathrm{b}}$ was slightly above $\mathrm{T}_{\mathrm{a}}$, between 0.3 to $0.5{ }^{\circ} \mathrm{C}$.

Fed Chilean mouse-opossum showed daily euthermic fluctuations in $\mathrm{T}_{\mathrm{b}}$ held under $\mathrm{LD}=$ 12:12 and $\mathrm{T}_{\mathrm{a}}$ of $20 \pm 2{ }^{\circ} \mathrm{C}$. During daylight hours mean $\mathrm{T}_{\mathrm{b}}$ was $34.5 \pm 2.0{ }^{\circ} \mathrm{C}$ at $09: 30 \mathrm{~h}$ and $34.4 \pm 1.5{ }^{\circ} \mathrm{C}$ at $15: 30 \mathrm{~h}(\mathrm{n}=12)$. At night $\mathrm{T}_{\mathrm{b}}$ was significantly higher, being $36.8 \pm 0.5^{\circ} \mathrm{C}$ at 03:50 $\mathrm{h}$ and $36.7 \pm 0.4{ }^{\circ} \mathrm{C}$ at $21: 00 \mathrm{~h}, \mathrm{n}=12$ (one-way ANOVA $F_{1,78}=41262, \mathrm{P}<0.00001$ ). Post-hoc Tukey test only revealed significantly differences between diurnal and nocturnal $T_{b}$ values $(\mathrm{P}<0.0001)$.

In an experimental $\mathrm{T}_{\mathrm{a}}$ of $15{ }^{\circ} \mathrm{C}$ and only when deprived of food, $T$. elegans 'entered in daily torpor and aroused spontaneously every night (Fig. 2). When in torpor $\mathrm{VO}_{2}$ falls nearly $1 / 100^{\text {th }}$ of that during euthermia. Body 
temperature during deep torpor was $0.5-1.0^{\circ}{ }^{\circ} \mathrm{C}$ $(\mathrm{n}=12)$ above $\mathrm{T}_{\mathrm{a}}$. Interestingly when we changed $\mathrm{T}_{\mathrm{a}}$ from 15 to $0{ }^{\circ} \mathrm{C}$, torpid animals aroused spontaneously (Fig. 3). Also, torpor bouts length lasted from 7 to $19 \mathrm{~h}$. When $\mathrm{T}_{\mathrm{a}}$ was changed to the initial conditions $\left(15{ }^{\circ} \mathrm{C}\right)$ animals become torpid again (Fig. 3). The same patterns of daily torpor in the absence of food were observed during all seasons, revealing a facultative type of torpor.

\section{DISCUSSION}

Marsupials in general have lower BMR than eutherian mammals (MacMillen \& Nelson 1969, McNab 2002, see McNab 2005 in this volume). Nevertheless McNab (1978) pointed out that Neotropical marsupials have somewhat higher $\mathrm{BMR}$ and $\mathrm{C}_{\mathrm{m}}$ values than Australian ones. Contrarily, Bozinovic et al. (2004) demonstrated that the South American living fossil Dromiciops gliroides does not support the energetic standards for Neotropical marsupials. These authors hypothesized that this is because Dromiciops is a well-differentiated lineage from South American opossums within the Australidelphian radiation of metatherians (Palma 2003). That is, hypothetically its physiological energetics seems to be phylogenetically closer to the Australian marsupials.

Nevertheless, T. elegans partially supports McNab's (1978) predictions, because BMR was higher but $\mathrm{C}_{\mathrm{m}}$ was lower than expected for their body mass. The higher mass-independent BMR of the Chilean mouse-opossum may be explained by its insectivorous food habits and its low $\mathrm{C}_{\mathrm{m}}$ by its temperate habitats (McNab (1978, 2002). In addition, Nespolo et al. (2002) measured thermoregulatory maximum metabolic rate and BMR in T. elegans, before and after acclimation to cold or warm conditions. These authors observed no significant effect of thermal acclimation on maximum metabolic rate however; BMR of cold acclimated animals was $30 \%$ higher than that for warm acclimated individuals, suggesting that BMR shows plasticity.

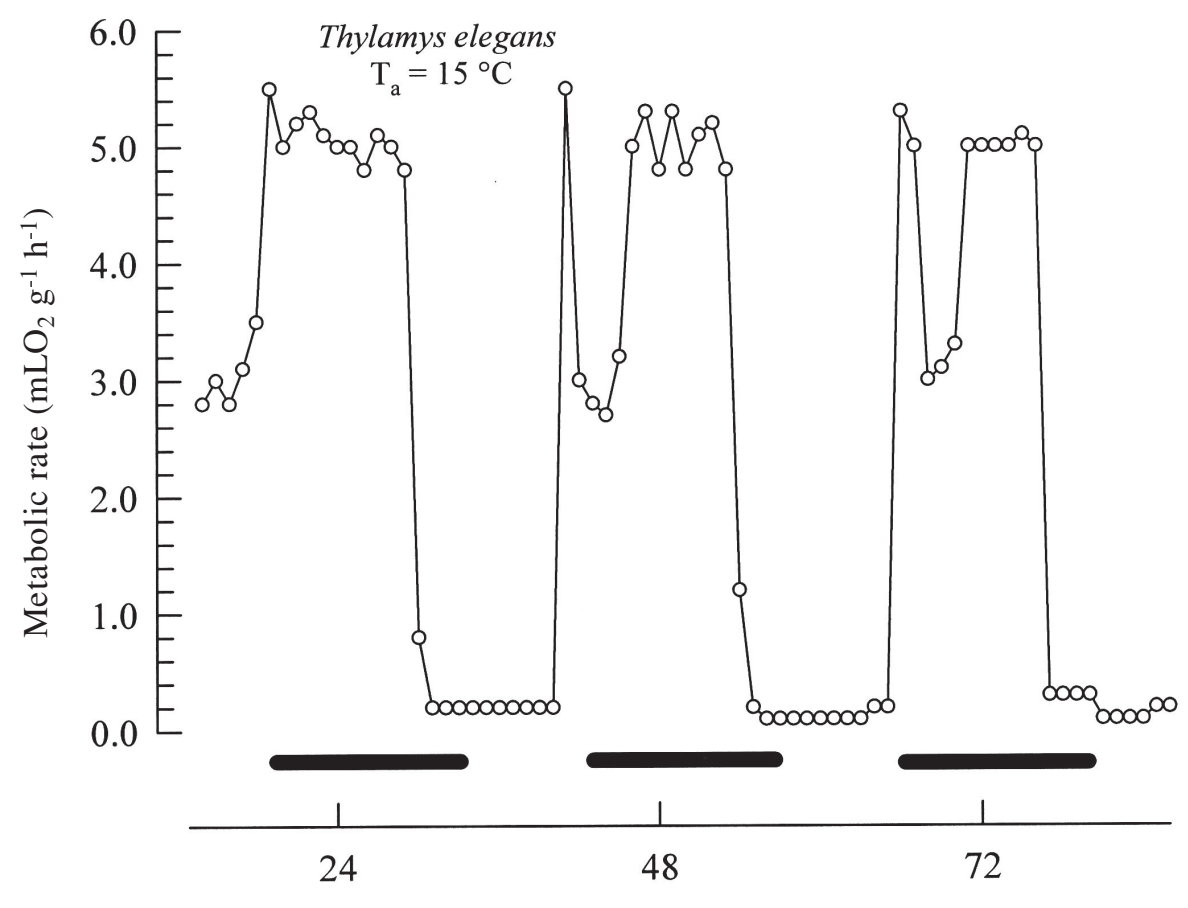

Time (h)

Fig. 2: Daily torpor in a representative individual of Thylamys elegans measured over a 3 days period at $15{ }^{\circ} \mathrm{C}$ without food. Bars indicated dark hours.

Sopor diario en un individuo representativo de Thylamys elegans medido durante 3 días a $15{ }^{\circ} \mathrm{C}$ sin alimento. Las barras indican las horas de oscuridad. 


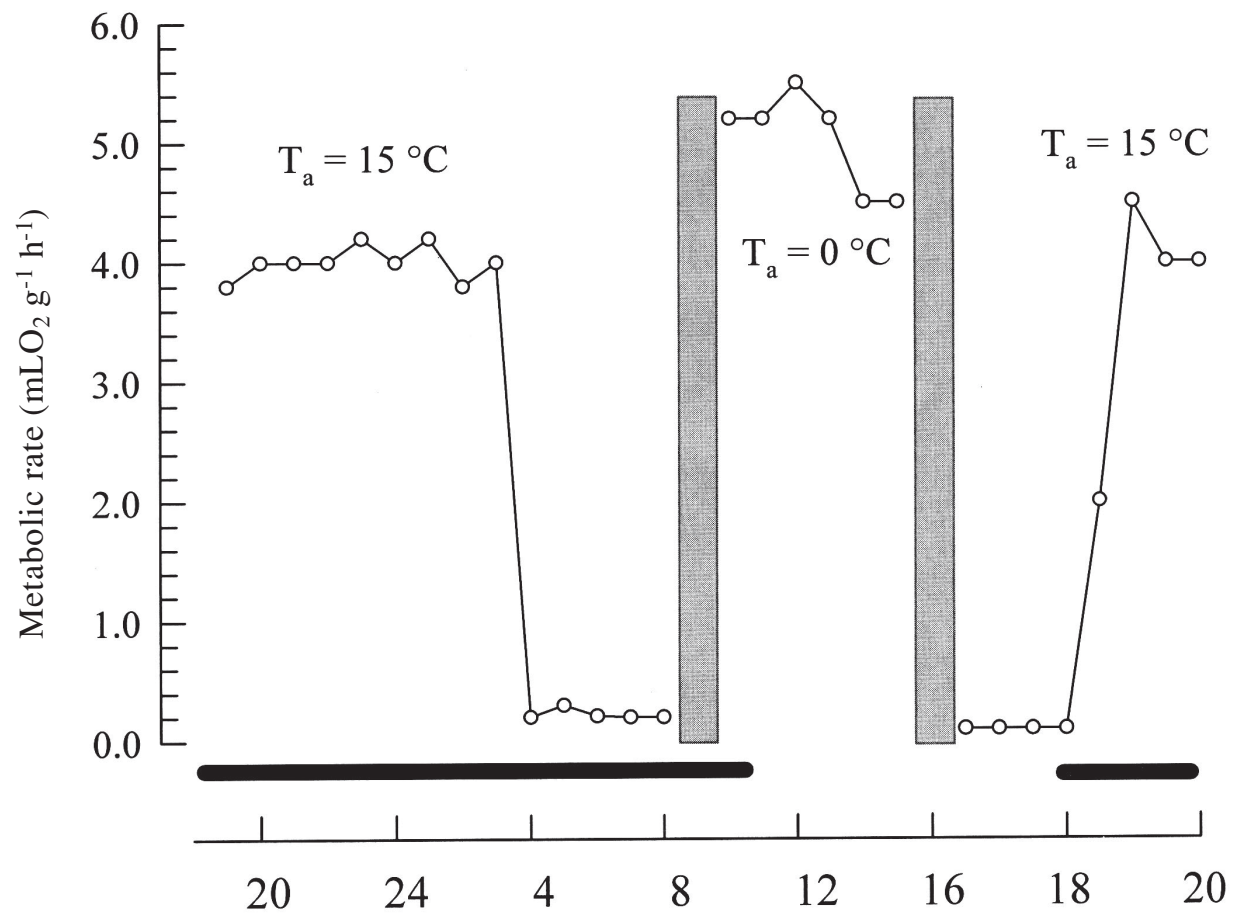

Time (h)

Fig. 3: Continuous changes in metabolic rate (euthermia and torpor) in a representative individual of Thylamys elegans at two different temperatures without food. Black bars indicated dark hours while the vertical grey bars indicate the time lag between changes in ambient temperature. Note that animals arouse from torpor at freezing temperature. See text for details.

Cambios continuos en la tasa metabólica (eutermia y sopor) en un individuos representativo de Thylamys elegans en dos temperaturas diferentes y sin alimento. Las barras negras indican las horas de oscuridad mientras que las barras grises el tiempo entre cambios de temperatura. Note que los animales sales del sopor a la temperatura de congelamiento. Véase el texto para detalles.

The combinations of high BMR and low $\mathrm{C}_{\mathrm{m}}$ by implying a continuous $\mathrm{T}_{\mathrm{b}}$ regulation, is likely to be advantageous for survival in temperate habitats (McNab 1992). The minimal temperature differential between body and ambient $\left(\Delta \mathrm{T}_{\mathrm{m}}\right)$ is equal to $\mathrm{BMR} / \mathrm{C}_{\mathrm{m}}(\mathrm{McNab}$, 1979). Indeed low mass-independent $C_{m}$ values (high thermal insulation) coupled to high massindependent BMR values may contribute to a higher thermoregulatory capacity by allowing heat conservation. The predicted $\Delta \mathrm{T}_{\mathrm{m}}$ for marsupials follow the equation: $2.49 \mathrm{~m}_{\mathrm{b}} 0.28$ (McNab 2002). In T. elegans the ratio BMR/C was $7.8{ }^{\circ} \mathrm{C}$ representing a $111.4 \%$ of the expected value for a $40.2 \mathrm{~g}$ standard marsupial. The high thermoregulatory capability of $T$. elegans may explain why this species never became torpid when food is available (SilvaDurán \& Bozinovic 1999).
Following Geiser's (1994) classificatory scheme of torpor in marsupials, T. elegans seems to display a facultative type of daily torpor. The propensity to enter in torpor was dependent of the combination of food absence and $\mathrm{T}_{\mathrm{a}}$. Torpor in this species as well as in marsupials in general appears to be a flexible and an opportunistic response to unpredictable environmental conditions (Geiser 1987). It is interesting to note that the tendency to become torpid at freezing temperatures was reduced (Fig. 3). We hypothesized that under these environmental conditions, this species should exhibit a controlled daily torpor avoiding physiologically risky conditions. Overall, the thermoregulatory energetic response of $T$. elegans during daily torpor was similar to the one reported for Australian species (Geiser (2003) as well as to that shown by some small 
eutherian hibernators (Kayser 1961), representing a fall to $1 / 100$ th of the metabolic rate of the euthermic animals.

Silva-Durán \& Bozinovic (1999) reported that the frequency of torpor in $T$. elegans varied with food availability. That is, these authors observed that with amounts of food that exceed daily energy requirements, animals were never torpid in contrast to animals confronted to lower availability of food. Moreover, the relationship between the length of torpor bouts and digestible energy intake indicates that food availability influences not only the frequency of torpor but also its length. In fact, Holloway \& Geiser (1995) indicate that the amount of energy saved during torpor was dependend not only on the level of metabolic rate, but also on the duration of torpor as well as on the amount of energy required for rewarming. We postulated that the reduction of energy expenditure achieved by a torpid animal is induced by food availability, i.e., regulation by energy supply (Ricklefs 1996). Besides, it has been shown that nutrient absorption in the digestive tract of torpid endotherms decreased when $\mathrm{T}_{\mathrm{b}}$ drops (Holloway \& Geiser 1995). Then, in terms of energy savings, it would be risky to maintain torpidity for long periods, given the low absorption of nutrients that it implicates. Nevertheless, in the absence of food it may allow an economy of energy. In addition, Silva-Durán \& Bozinovic (1999) also observed that, in spite of an increase in food availability, animals did not increase energy expenditure, probably because such augmentation results in extra energy costs. On the other hand, when food availability was low, animals decreased metabolic rate to a minimum that should be maintained even under the lowest food availability. Apparently, there is a physiological constraint set by the energy needed for arousal, which represents the greatest energy cost within the torpid cycle (Opazo et al. 1999). Interestingly, winteracclimated Djungarian hamsters (Phodopus sungorus) enter torpor spontaneously with food ad lib when their thermogenic capacity is high (Heldmaier \& Steinlechner 1981).

The habitat of $T$. elegans may be described as an evergreen scrub, locally know as matorral. The climate is Mediterranean, with an annual mean rainfall of $376.4 \mathrm{~mm}$, concentrated
(65\%) during the winter months. On average, it rains every month of the year, but precipitation is scant during late spring and summer (3\% of the yearly total). Mean temperature is highest from late spring and summer and lowest during the austral winter. The combination of high temperature and low precipitation occurs during summer, thus determining a summer drought. Since this habitat is seasonal in both water and food availability, torpor appears to be important in water and energy economy. Thus, depending of the local environmental conditions, we postulate that there is a trade off between the need to satisfy energy/water requirements through foraging and the necessity to increase energy/water savings through torpor. Furthermore, as postulated by Geiser (1986) torpor appears to have importance in the survival of individuals mainly in a highly seasonal and unproductive habitat (see Humphries et al. 2003).

In summary, the observed flexibility in torpor states dealing with energy and water economy may favour survival and reproduction. News studies dealing with the variability of thermoregulatory strategies during torpor are needed. For example, Cryan \& Wolf (2003) demonstrated that during reproduction females of heterothermic bats defend euthermia, presumably to expedite embryonic growth, while males use torpor, presumably to minimize energy and water deficits.

\section{ACKNOWLEDGEMENTS}

This paper is dedicated to the memory of our coauthor, friend and mentor, Mario "Profe" Rosenmann. FB acknowledges a FONDAP 1501-0001 (Program 1) grant.

\section{LITERATURE CITED}

BOZINOVIC F \& MA MÉNDEZ (1997) Role of dietary fatty acids on energetics and torpor in the Chilean mouse-opossum Thylamys elegans. Comparative Biochemistry and Physiology 116A: 101-104.

BOZINOVIC F \& M ROSENMANN (1988a) Daily torpor in Calomys musculinus, a South American rodent. Journal of Mammalogy 69: 150-152.

BOZINOVIC F \& M ROSENMANN (1988b) Comparative energetics of South American cricetid rodents. 
Comparative Biochemistry and Physiology 91A: 195-202.

BOZINOVIC F \& PA MARQUET (1991) Energetics and torpor in the Atacama desert-dwelling rodent Phyllotis darwini rupestris. Journal of Mammalogy 72: 734-738.

BOZINOVIC F, G RUIZ \& M ROSENMANN (2004) Energetics and torpor of a South American living fossil, the Microbiotheriid'Dromiciops gliroides Journal of Comparative Physiology B 174: 293 297.

CAVIEDES-VIDAL E, EC CAVIEDES, V ROIG \& R DOÑA (1990) Facultative torpor in the South American rodent Calomys venustus (Rodentia: Cricetidae). Journal of Mammalogy 71: 72-75.

CHAPPELL MA \& TJ DAWSON (1994) Ventilatory accomodation of changing oxygen consumption in Dasyurid marsupials. Physiological Zoology 67: 418-437.

CRYAN P M \& BO WOLF (2003) Sex differences in the thermoregulation and evaporative water loss of a heterothermic bat, Lasiurus cinereus, during its spring migration. Journal of Experimental Biology 206: 3381-3390.

GEISER F (1987) Hibernation and daily torpor in two pygmy possums (Cercartetus spp., Marsupialia). Physiological Zoology 60: 93-102.

GEISER F (1988) Reduction of metabolism during hibernation and daily torpor in mammals and birds: temperature effect or physiological inhibition? Journal of Comparative Physiology 158: $25-37$

GEISER F (1994) Hibernation and daily torpor in marsupials: a review. Australian Journal of Zoology 42: 1-16.

GEISER F (1996) Thermoregulation and torpor in the Kultarr, Antechinomys laniger (Marsupialia: Dasyuridae). Journal of Comparative Physiology B 156: 751-757.

GIBSON LA \& ID HUME (2000) Seasonal field energetics and water influx rates of the greater bilby (Acrotis lagotis). Australian Journal of Zoology 48: 225-239.

HAINSWORTH FR, BG COLLINS \& LL WOLF (1977) The function of torpor in hummingbirds. Physiological Zoology 50: 215-222.

HALLAM JF \& TJ DAWSON (1993) The pattern of respiration with increasing metabolism in a small dasyurid marsupial. Respiration Physiology 93: 305-314.

HELDMAIER G \& S STEINLECHNER (1981) Seasonal pattern and energetics of short daily torpor in the Djungarian hamster Phodopus sungorus. Oecologia 48: 265-270.

HERREID CF \& B KESSEL (1967) Thermal conductance in birds and mammals. Comparative Biochemistry and Physiology 21: 405-414.

HOLLOWAY JC \& F GEISER (1995) Influence of torpor on daily expenditure of the dasyurid marsupial Sminthopsis crassicaudata. Comparative Biochemistry and Physiology 112A: 59-66.

HOLLOWAY JC \& F GEISER (2001) Effects of helium/ oxygen and temperature on aerobic metabolism in the marsupial sugar glider, Petaurus breviceps. Physiological and Biochemical Zoology 74: 219. 225.

HUMPHRIES MW, DW THOMAS \& DL KRAMER (2003) The role of energy availability in mammalian hibernation: a cost-benefit approach. Physiological and Biochemical Zoology 76: 165179.
KENAGY GJ (1973) Daily and seasonal patterns of activity and energetics in a heteromyid rodent community. Ecology 54: 201-1219.

KAYSER C (1961) The physiology of natural hibernation. Pergamon Press, Oxford, United Kingdom. 325 pp.

LÓPEZ-CALLEJA MV, F BOZINOVIC \& C MARTÍNEZ DEL RÍO (1997) Effect of sugar concentration on hummingbird feeding and energy use. Comparative Biochemistry and Physiology 118A: 1291-1299.

MACMILLEN RE \& JE NELSON (1969) Bioenergetics and body size in dasyurid marsupials. American Journal of Physiology 217: 1246-1251.

McNAB BK (1979) Climatic adaptation in the energetics of heteromyid rodents. Comparative Biochemistry and Physiology 62: 813-820.

McNAB BK (1979) The comparative energetics of Neotropical marsupials. Journal of Comparative Physiology B 125: 115-128.

McNAB BK (1992) The comparative energetics of rigid endothermy: the Arvicolidae. Journal of Zoology (London) 227: 585-606.

McNAB BK (2002) The physiological ecology of vertebrates. A view from energetics. Cornell University Press, Cornell. 576 pp.

McNAB BK (2005) Uniformity in the basal metabolic rate of marsupials: its causes and consequences. Revista Chilena de Historia Natural 78: 000-000.

MORRISON PR (1951) An automatic manometric respirometer Review of Scientific Instruments 22: 264-267.

NESPOLO RF, LD BACIGALUPE, P SABAT \& F BOZINOVIC (2002) Interplay among energy metabolism, organ masses and digestive enzyme activity in the mouse-opossum, Thylamys elegans: the role of thermal acclimation. Journal of Experimental Biology 205: 2697-2703.

OPAZO J C, RF NESPOLO \& F BOZINOVIC (1999) Arousal from torpor in the Chilean mouse-opossum (Thylamys elegans): does non-shivering thermogenesis play a role? Comparative Biochemistry and Physiology A 123: 393-397.

ORTMANN S \& G HELDMAIER (1997) Spontaneous daily torpor in Malagasy mouse lemurs. Naturwissenschaften 84: 28-32.

PALMA ER (2003) Evolution of American marsupials and their phylogenetic relationships with Australian metatherians. In: Jones $\mathrm{M}$, Ch Dickman \& M Archer (eds) Predator with pouches: the biology of carnivorous marsupials: 21-29. CSIRO Publishing, Collingwood, Australia.

RICKLEFS RE (1996) Avian energetics, ecology and evolution. In: Carey C (ed) Avian energetics and nutritional ecology: 1-30.Chapman \& Hall, New York, New York, USA.

ROIG V G (1971) Presencia de estados de hibernación en Marmosa elegans (Marsupialia: Didelphidae). Acta Zoologica Lilloana (Argentina) 28: 5-12.

SABAT P \& F BOZINOVIC (1994) Cambios estacionales en la actividad de enzimas digestivas en el pequeño marsupial Thylamys elegans: disacaridasas intestinales. Revista Chilena de Historia Natural 67: 221-228.

SABAT P, F BOZINOVIC \& F ZAMBRANO (1995) Role of dietary substrates on intestinal disaccharidases, digestibility and energetics in the insectivorous mouse-opossum (Thylamys elegans). Journal of Mammalogy 76: 603-611.

SCHMIDT-NIELSEN K (1987) Animal physiology: adaptation and environment. Third edition. Cambridge University Press, Cambridge, Massachusetts, USA. 602 pp. 
SILVA-DURÁN I P \& F BOZINOVIC (1999) - Food availability regulates energy expenditure and torpor in the Chilean mouse-opossum - Thylamys elegans. Revista Chilena de Historia Natural 72: 371-376.

Associate Editor: Luis Ebensperger

Received Dember 2, 2004; accepted March 1, 2005
STATISTICA (2001) Statistica (Quick Reference) for the Windows operating system. StatSoft, Inc., Tulsa, Oklahoma. 